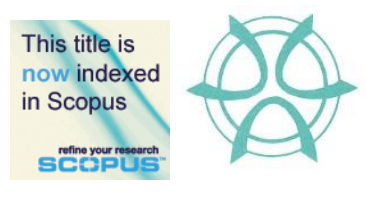

PLANNING MALAYSIA:

Journal of the Malaysian Institute of Planners

VOLUME 15 ISSUE 2 (2017), Page 25 - 36

\title{
COMBATING SQUATTERS IN MALAYSIA: DO WE HAVE ADEQUATE POLICIES AS INSTRUMENT?
}

\author{
Yusfida Ayu Abdullah', Julieven Nonoi Kuek², Hazlina Hamdan³, \& Farrah \\ Lyana Mohd Zulkifli ${ }^{4}$ \\ ${ }^{1,2,3,4}$ Faculty of Architecture, Planning and Surveying \\ UNIVERSITI TEKNOLOGI MARA (UiTM)
}

\begin{abstract}
The year 2014 had witnessed the scenario where most of the states in Malaysia pledged to declare themselves as Zero Squatter state. Thus far, most of the states in Malaysia are still striving to achieve the goal. The government has therefore aspires to reach the target by the year 2020. The Malaysian government under its 5 -years National Plan has since introduced the low, medium and high cost housing categories. The housing policy was therefore designed to provide the public of all income levels, particularly the low-income groups, with affordable housing as part of an effort to eradicate squatters. However, despite the various policies, the number of squatter families remains large, especially in the urban areas. This paper therefore, intends to examine the instruments put forward by the government to eliminate squatters and assess the roles of related parties assigned to achieve the government's mission. Through a qualitative approach, results demonstrated that Malaysia has various types of polices and guidance at both the federal and state levels in relation to low-cost housing provision. These would have supposed to help reduce the number of squatters in the country. However, to date, Malaysia is still experiencing problems with squatters. This calls for further investigation.
\end{abstract}

Keywords: squatters, housing policies, housing programmes, low-cost housing.

Date Received: $26^{\text {th }}$ July 2016

Date of Acceptance: $6^{\text {th }}$ July 2017 
Yusfida Ayu Abdullah, Julieven Nonoi Kuek, Hazlina Hamdan, \& Farrah Lyana Mohd Zulkifli

Combating Squatters in Malaysia: Do We Have Adequate Policies as Instrument?

\section{INTRODUCTION}

The rapid development in a city is one of the factors that attract rural communities to migrate and experience urban life (Agus, 2005). Inevitably, urban areas are forced to face the challenges of squatters and housing shortages due to the increased population (UN-Habitat, 2008). The problem of poverty in a city often exists in squatter areas in the suburbs. For so long, the issue of squatters continues to be a major problem in the urban areas in Malaysia. According to the Ministry of Urban Wellbeing, Housing and Local Government (2015a), squatters can be defined as an exploration activity, or occupation or construction of buildings on lands belonging to other parties (whether government or private land). Before 1970, Malays were generally lived in rural areas, while the Chinese lived in urban areas and most Indians lived in rubber or oil palm estates (Tan, 2011). Hence, the New Economic Policies (NEP) was introduced in 1970 to promote national unity through eradicating poverty, controlling the society and bring to an end the identification of race by economic activity and geographic location. As one of the NEP strategies, the Malays were therefore urged to migrate to urban areas to break the character of urban population that was dominated by the Chinese (Tan, 2011). Thus, the rapid rate of migration of the rural Malays to urban centres in 1980 had caused the increasing need for low-cost housing in cities and resulted to the opening of squatter settlements (Tan, 2011).

Since most of the economic activities are concentrated in cities, therefore the rural communities are attracted to migrate to urban areas. The migration to major cities not only had led to the opening of new squatter areas but also crammed the existing areas (Shresta et al, 2014). The problem then has become complicated to regulate although there are laws that forbid people to reside on state land illegally. The authorities have been controlling against illegal land occupation, but some people defy the law and enforcement (Sufian, 2009). According to Murad et al. (2014), the first city to experience the highest number of squatters was Kuala Lumpur, where $32 \%$ of the Kuala Lumpur's population in 1968 were squatters and later increased to $37 \%$ in 1971 . To eradicate the squatters, the government began squatters clearance programme in 1998 (Muhamad Ariff \& Davies, 2009). Thereafter, the 'Zero Squatter by 2005' Program was launched in 2000. However, despite the programme, until now there are still many squatters left in the urban areas (Murad et al., 2014).

In Malaysia, most of the occupants of low-cost housing are former squatters or from low-income group. Since 2005, squatters have gained attention from the federal and state governments. Various approaches have been considered in attempting to stop the growth of squatter areas or to even upgrade the facilities within the squatter areas. The government had then geared up to build more lowcost housing or affordable housing for sale and rent to relocate the squatters and achieve the Zero Squatter mission by the year 2020 (Tan, 2011). Nevertheless, low cost housing programmes face challenges including mismatch between 
PLANNING MALAYSIA

Journal of the Malaysia Institute of Planners (2017)

demand and supply, house price increase, lack of integrated planning and implementation, poor maintenance, and insufficient amenities (Economic Planning Unit, 2015).

This paper aims to examine the policies that have been formulated as instruments in eradicating urban squatters in Malaysia, and to assess the role of the related parties in delivering the low-cost housing initiatives. Data was mainly obtained through document analysis of related government policies, reports and statistics.

\section{MALAYSIA HOUSING POLICIES}

The government's policies on housing had started much earlier than the NEP. Housing was already seen as important from the 1960s. Strategies and programmes were by now planned since the First Malaysia Plan in 1966. Over the years, Malaysia Plans has evolved and during the 1990s onwards, the focus has been on the provision of housing for the lower income group (Table 1).

Since independence in 1957, the government has continuously encouraging the public to own a house. The involvement of government in housing is through the federal and state governments. The federal government through the Ministry of Urban Wellbeing, Housing and Local Government is in charge in making policies and guidelines for housing provision. Meanwhile, the National Housing Department, a department under the Ministry, is responsible in delivering lowcost housing throughout the country with assistance from the state governments. Other government statutory bodies such as Urban Development Authority (UDA) or Regional Development Agencies (RDA) also deliver housing schemes but their housing programmes are targeted for particular group or development in specific areas (Shuid, 2004).

Table 1 Five-Years Malaysia Plans

\begin{tabular}{ll}
\hline Malaysia Plan & Objectives \\
\hline $\begin{array}{l}1^{\text {st }} \text { Malaysia Plan } \\
(1966-1970) ; \text { and } \\
2^{\text {nd }} \text { Malaysia Plan } \\
(1970-1975) .\end{array}$ & $\begin{array}{l}\text { Promote welfare of all Malaysian regardless of ethnic } \\
\text { background by providing improved housing, community } \\
\text { facilities, welfare and other services. }\end{array}$ \\
\hline $\begin{array}{l}3^{\text {rd }} \text { Malaysia Plan } \\
(1976-1980)\end{array}$ & $\begin{array}{l}\text { The goal of housing is to eradicate poverty and restructure } \\
\text { the society. }\end{array}$ \\
\hline $\begin{array}{l}4^{\text {th }} \text { Malaysia Plan } \\
(1981-1985)\end{array}$ & Continuation of the goal of the previous five years plan \\
\hline & $\begin{array}{l}\text { Housing programmes were implemented in the context of } \\
\text { human settlement concept. The provision of social } \\
\text { facilities, such as: schools, clinic, community halls was } \\
\text { emphasized rather than the provision of basic } \\
\text { (1986-1990) }\end{array}$ \\
\end{tabular}


Yusfida Ayu Abdullah, Julieven Nonoi Kuek, Hazlina Hamdan, \& Farrah Lyana Mohd Zulkifli

Combating Squatters in Malaysia: Do We Have Adequate Policies as Instrument?

\begin{tabular}{|c|c|}
\hline $\begin{array}{l}6^{\text {th }} \text { Malaysia Plan } \\
(1991-1995)\end{array}$ & $\begin{array}{l}\text { Home owning within various income groups was } \\
\text { emphasized. }\end{array}$ \\
\hline $\begin{array}{l}7^{\text {th }} \text { Malaysia Plan } \\
(1996-2000)\end{array}$ & $\begin{array}{l}\text { Low medium cost house was introduced. House price was } \\
\text { divided into low-cost housing (below RM 42,000), low- } \\
\text { medium cost (RM 42,000-RM 60,000), medium cost (RM } \\
60,001 \text { - RM 100,000) and high cost (more than RM } \\
\text { 100,000). }\end{array}$ \\
\hline $\begin{array}{l}8^{\text {th }} \text { Malaysia Plan } \\
(2001-2005)\end{array}$ & $\begin{array}{l}\text { The priority was the development of low-and low-medium } \\
\text { cost houses. Both public and private sectors were urged to } \\
\text { cooperate with each other to meet the increasing demand } \\
\text { for housing. }\end{array}$ \\
\hline $\begin{array}{l}9^{\text {th }} \text { Malaysia Plan } \\
(2006-2010)\end{array}$ & $\begin{array}{l}\text { To ensure that all Malaysian, especially those in the low } \\
\text { and low-medium income groups, will have access to } \\
\text { adequate, quality and affordable house. }\end{array}$ \\
\hline $\begin{array}{l}10^{\text {th }} \text { Malaysia Plan } \\
(2011-2015)\end{array}$ & $\begin{array}{l}\text { To increase homeownership in which was based on the } \\
\text { ability to pay and provided affordable and quality house for } \\
\text { the poor and low income group. }\end{array}$ \\
\hline $\begin{array}{l}11^{\text {th }} \text { Malaysia Plan } \\
(2016-2020)\end{array}$ & $\begin{array}{l}\text { Continuation of existing affordable housing programs as } \\
\text { well as enhancing the involvement of private sector in the } \\
\text { provision of affordable houses. And, increase the delivery } \\
\text { of affordable housing to specific group with suitable } \\
\text { facilities. }\end{array}$ \\
\hline
\end{tabular}

Source: Economic Planning Unit (2016)

Overall, the housing-related objectives of the Malaysia Plans are multipronged. The housing programmes by the governments are mainly initiated as part of the efforts by the governments to help the low-income group to afford a house, to reduce poverty and to resettle squatters (Bakhtyar et al., 2013; Besar, Fauzi \& Ghazali, 2012; Abdul Aziz, 2012) (Table 2).

Table 2 Public Housing Programmes

\begin{tabular}{ll}
\multicolumn{1}{c}{$\begin{array}{c}\text { Public Housing } \\
\text { Program }\end{array}$} & \multicolumn{1}{c}{ Description } \\
\hline $\begin{array}{l}\text { Perumahan } \\
\text { Awam Kos } \\
\text { Rendah (PAKR) }\end{array}$ & $\begin{array}{l}\text { The Federal Government provides funding in the form of loan to } \\
\text { the state governments to build low-cost houses. Detached or semi- } \\
\text { detached houses (mostly made from wood) outside the city or } \\
\text { two-storeys terraced houses, and flats in urban areas. }\end{array}$ \\
\hline $\begin{array}{l}\text { Perumahan } \\
\text { Awam Kos }\end{array}$ & $\begin{array}{l}\text { Lowdah } \\
\text { Bersepadu } \\
\text { (PAKRB) }\end{array}$ \\
$\begin{array}{l}\text { Site and Services } \\
\text { Scheme } \\
\text { Karly 1970) }\end{array}$ & $\begin{array}{l}\text { For low-income households for rental to overcome the problem of squatters in } \\
\text { PAKR. }\end{array}$ \\
\hline
\end{tabular}


- Site preparation and foundation for a house that is designed or constructed that allows the owner to upgrade the house later.

- Develop vacant sites including basic facilities.

\begin{tabular}{ll}
\hline Program & To provide comfortable houses with adequate infrastructure and \\
Perumahan & basic amenities in suitable locations. Implemented to address the \\
Rakyat (PPR) & $\begin{array}{l}\text { increasing demand for affordable housing among the low-income } \\
\text { households, particularly in urban areas. }\end{array}$ \\
\hline
\end{tabular}

- Squatters needing finance to build a new house on the land allocated to them.

- Housing for settlers provided by the Ministry of Rural and Regional Development and regional development agencies

Housing Loan Scheme - scheme for low income groups who cannot get financing from other sources. such as the Federal Land Development Authority (FELDA), The Federal Land Consolidation and Rehabilitation Authority (FELCRA), South Johor Development Authority, Central Terengganu Development Authority (KETENGAH), South Kelantan Development Authority (KESEDAR).

- Quarters for civil servants.

- Employee housing estates and industrial (Akta Standard Minimum Perumahan dan Kemudahan Pekerja 1990) where the owner of the estate provides free housing and social facilities that are appropriate to their employees.

\begin{tabular}{|c|c|}
\hline $\begin{array}{l}\text { Syarikat } \\
\text { Perumahan } \\
\text { Negara Berhad } \\
(\text { SPNB })-(2014)\end{array}$ & $\begin{array}{l}\text { - Affordable housing for low and middle income groups. } \\
\text { - SPNB is the implementing agency for the rehabilitation } \\
\text { abandoned housing projects in order to monitor and rehabilita } \\
\text { abandoned projects and build homes for the disadvantaged. }\end{array}$ \\
\hline $\begin{array}{l}\text { Perumahan } \\
\text { Rakyat } 1 \\
\text { Malaysia } \\
\text { (PR1MA) - } \\
(2014)\end{array}$ & $\begin{array}{l}\text { - Develop and maintain quality affordable housing for middle } \\
\text { income group. } \\
\text { - House price between RM 100,000 to RM 400,000 in major } \\
\text { cities. }\end{array}$ \\
\hline
\end{tabular}
(2014)

Perumahan

Penjawat Awam

1 Malaysia

(PPA1M) -

(2014)

Source: Economic Planning Unit (2013)

Since the $1^{\text {st }}$ Malaysia Plan (1966-1970), public low-cost housing programmes have been implemented under the New Economic Policy (NEP) to reshape the urban demography and reduce inequalities among different ethnic groups in urban area (Ubale, Martin \& Seow, 2012). In the $3^{\text {rd }}$ Malaysia Plan (1976-1980), private sectors began to get involved in the provision of low cost housing.

In combating squatters, the government has established the Program Perumahan Rakyat Bersepadu (PPRB), or Integrated People's Housing 
Yusfida Ayu Abdullah, Julieven Nonoi Kuek, Hazlina Hamdan, \& Farrah Lyana Mohd Zulkifli

Combating Squatters in Malaysia: Do We Have Adequate Policies as Instrument?

Programme, in December 1998. The programme was introduced by the National Economic Action Council (NEAC). The objective of this programme was to resolve squatter problems in urban areas especially in the Federal Territory of Kuala Lumpur and other major cities. Meanwhile, for existing squatter settlements, the provision of basic amenities such as electricity and water was continued while waiting for a relocation program to new housing scheme.

In the $9^{\text {th }}$ Malaysia Plan (2006-2010), the state governments continue to emphasize on the objective of Zero Squatter by year 2020. Therefore, the private sector was required to build more low and low-medium cost houses in their housing projects. In the meantime, the public sector concentrated on the provision of low-cost houses as well as houses for public sector employees and the poor people in urban and rural areas (Tan, 2011). The federal government played a prominent role in the low-cost housing primarily through policy statements that set out goals for both public and private sectors as well as incentives to ease the process (Shuid, 2004) (Table 3).

Table 3 Federal Government Housing Policies for the Private Sector

\begin{tabular}{|c|c|}
\hline Condition & Explanation \\
\hline $\begin{array}{l}30 \% \text { Low-Cost } \\
\text { Component }\end{array}$ & $\begin{array}{l}\text { All private housing developers of projects above a certain } \\
\text { threshold to construct at least } 30 \% \text { low-cost housing units. }\end{array}$ \\
\hline 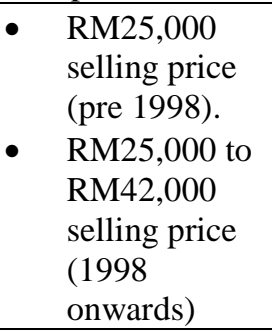 & $\begin{array}{l}\text { Houses constructed under the low-cost component can be sold } \\
\text { at a price not exceeding RM42,000 depending on location. }\end{array}$ \\
\hline 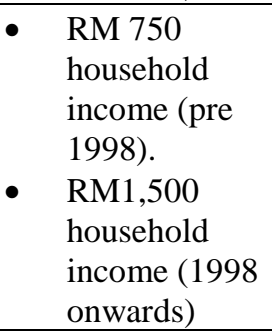 & $\begin{array}{l}\text { Buyers of the low-cost units must have a combined household } \\
\text { income not exceeding RM } 750 \text { per month for the units priced at } \\
\text { RM25,000. About } 60 \% \text { or urban households in Malaysia in } \\
1980 \text { were in this group. }\end{array}$ \\
\hline $\begin{array}{l}\text { Minimum Design } \\
\text { Standards }\end{array}$ & $\begin{array}{l}\text { Each low-cost house with a minimum built up area of } 550 \text { to } 600 \\
\text { square feet comprising two bedrooms, a living room, a kitchen } \\
\text { and a bathroom. The houses may be of any type including flats, } \\
\text { terrace or semi-detached houses. }\end{array}$ \\
\hline
\end{tabular}

At the federal level through the National Housing Department, the government promoted the people's housing program (PPR) and low-cost public 
PLANNING MALAYSIA

Journal of the Malaysia Institute of Planners (2017)

housing program (PAKR). Both types of housing programmes have a standardized size of floor area of not less than 700 square feet, consisting of three bedrooms, a living area, a kitchen, a bathroom and a toilet (National Housing Council, 2016) (Table 4).

Table 4 Characteristics of PPR Housing

\begin{tabular}{ll}
\hline Target Group & $\begin{array}{l}\text { Squatter dwellers with monthly income below RM2,500 (applicant } \\
\text { must not own a house yet). }\end{array}$ \\
\hline Type of House & $\begin{array}{l}5 \text { to } 18 \text { storeys flats in major cities and terrace houses in suburban } \\
\text { areas. }\end{array}$ \\
\hline Size of House & Not less than 700 square feet. \\
\hline Features & 3 bedrooms, 1 living room, 1 kitchen area, 1 bath, 1 toilet. \\
\hline Rental Rate & RM124 per month \\
\hline Source: National Housing Council, 2016.
\end{tabular}

\section{Zero Squatters Policy}

One of the first initiatives taken by state governments to resolve the squatter issue was by verifying the old and new squatter settlements. The local authorities were to straightaway demolish any squatter settlements built after the $1^{\text {st }}$ January 1998 , and this was determined through cooperation with the local Department of Statistics (Abdul Aziz, 2012). The 'Zero Squatter 2005' policy was introduced in 2001 to ensure that by year 2005, everyone in the whole state would legally own a house and aimed to offer the chance for its residents to benefit from a balanced social development with the motto 'one family one house, a perfect family comes from a perfect home' (Abdul Aziz, 2012). In Selangor, the focus was to eradicate squatters and provide low-cost housing within five years, from February 2000 to December 2004 (Figure 1). In relation to this, the local authorities played an important role in its implementation (Table 5). The relocation of squatter dwellers to low-cost housing includes (a) in-situ relocation, where squatter settlement sites were re-developed for low-cost housing, (b) relocation within election zone, where squatters were relocated to low-cost housing built within similar election zone, (c) relocation to the nearest election zone, where squatters were resettled to low-cost houses built in the nearest election zone (Abdul Aziz, 2012). 


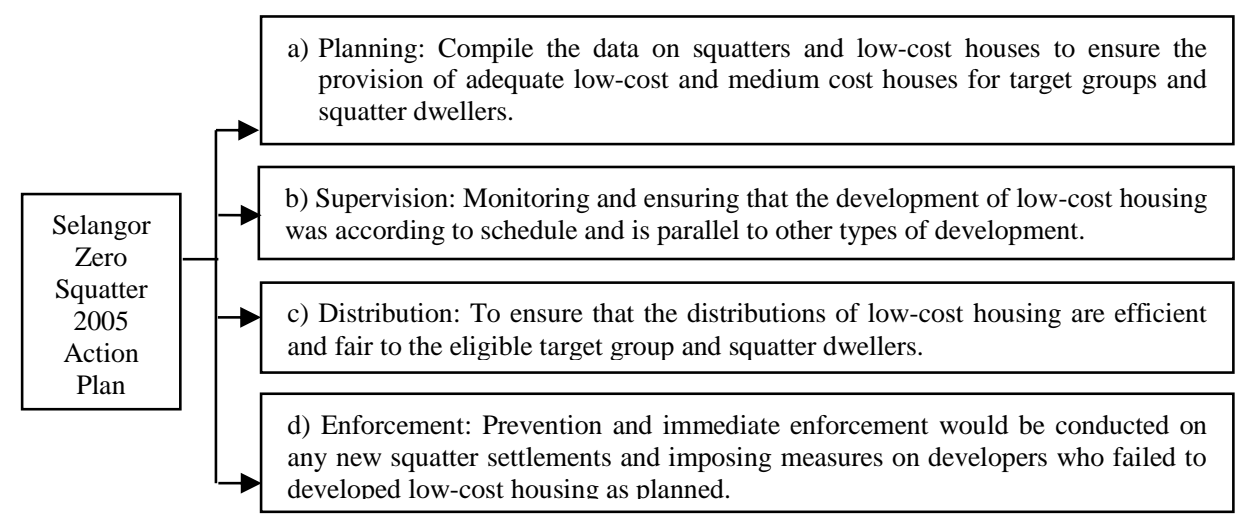

Figure 1 The Zero Squatter Action Plan by Selangor State Government Source: Abdul Aziz, 2012.

Table 5 The Roles of Local Authority in Eradicating Squatter Settlements

\begin{tabular}{|c|c|}
\hline Secretariat Unit & Task Force Unit \\
\hline $\begin{array}{l}\text { - Led by planning officer. } \\
\text { - Manage all meetings and anything } \\
\text { related to squatters and development } \\
\text { of low-cost housing. } \\
\text { Monitor the development low-cost } \\
\text { housing. } \\
\text { Manage the census and survey } \\
\text { process of squatters. }\end{array}$ & $\begin{array}{l}\text { - Involve the state assembly members } \\
\text { to ensure speedy development of } \\
\text { low-cost housing. } \\
\text { - To assist in resolving squatter issues } \\
\text { with regards to low-cost housing and } \\
\text { squatters. } \\
\text { To identify and resolve problematic } \\
\text { low-cost housing development. }\end{array}$ \\
\hline
\end{tabular}

\section{DISCUSSION}

In June 1998, the federal government had introduced the new policy for low-cost housing. The introduction of moratorium to stop low-cost house buyers from selling the house within 10 years after purchase was one of the guidelines introduced by the government (Ubale, Martin \& Seow, 2012). However, the $30 \%$ of low-cost housing quota in every housing development projects remained. The policies for low-cost housing implemented since 1971 to 2005 managed to produce a total number of 1,030,210 units of low-cost housing units built by the public and private sectors (National Housing Department, 2007). Even though there were many low-cost houses developed by the government and the establishment of various government programs as well as regulation to enforce private sectors to construct low-cost housing for the low-income group, still the number of squatter families had increased as shown in Table 6. 
PLANNING MALAYSIA

Journal of the Malaysia Institute of Planners (2017)

Table 6 The Number of Squatters in Malaysia, 2015

\begin{tabular}{lcc}
\hline State & $\begin{array}{c}\text { Number of } \\
\text { Families }\end{array}$ & $\begin{array}{c}\text { Number of } \\
\text { Family Members }\end{array}$ \\
\hline Johor & 11,151 & 31,553 \\
Kedah & 2,703 & 13,255 \\
Kelantan & 1,685 & 7,780 \\
Melaka & 7 & 19 \\
Negeri Sembilan & 195 & 382 \\
Pahang & 1,134 & 5,632 \\
Perak & 1,709 & 6,836 \\
Perlis & 1,853 & 8,570 \\
Pulau Pinang & 4,208 & 18,909 \\
Sabah & 28,087 & 133,059 \\
Sarawak & 8,431 & 35,233 \\
Selangor & 2,542 & 3,299 \\
Terengganu & 469 & 1,976 \\
Wilayah Persekutuan Kuala Lumpur & 3,217 & 12,868 \\
Wilayah Persekutuan Labuan & 970 & 5,521 \\
\hline Total & 68,861 & 284,892 \\
\hline Source: Ministry of Urban Wellbeing Housing and Local Government, $2015 b$. &
\end{tabular}

Despite the $5^{\text {th }}$ Malaysia Plan's 'Zero Squatter 2005' policy, the number of squatters in Malaysia remained large. Statistics show that in 2015, there were a total of 68,861 squatter families in Malaysia, which was an increase of 4,732 squatter families from 64,129 in 2013 (Jabatan Perancangan Bandar dan Desa, 2013). Data in Table 5 show that, in 2015, Sabah had the highest number of squatters with a total of 28,087 families. In Peninsualr Malaysia, Johor was the state with the highest number of squatter families with a total number of 11,151 . The Johor's policy for low-cost housing applies to any housing development of more than five (5) acres, which requires $40 \%$ of the total housing units to be of low-cost units, except in the District of Johor Bahru where $30 \%$ are required for low-cost houses and another $10 \%$ are for low-medium cost houses.

In Kuala Lumpur, the number of squatters was also high despite the various policies formulated by the city hall to mitigate the problem of squatters. The city hall's Town Planning Committee had issued guidelines for planning and development to ensure that the Kuala Lumpur Structure Plan housing strategy is achieved (Idrus \& Ho, 2008). Figure 2 outlines the policies for the provision of low-cost housing in Kuala Lumpur. 
Yusfida Ayu Abdullah, Julieven Nonoi Kuek, Hazlina Hamdan, \& Farrah Lyana Mohd Zulkifli Combating Squatters in Malaysia: Do We Have Adequate Policies as Instrument?

a) Every Housing Project of more than 5 Acres should allocate 30\% of the area for low-cost housing

b) The minimum size per unit of low-cost house is 550 sq. feet with 3 bedrooms and selling price of RM25,000 per unit.

c) Low-cost houses should be sold through the Housing Management Department (KL City Hall)

:

d) The construction of low-cost houses should start at the middle stage of the project. The project should not slow down the development of low-cost units.

Figure 2 Low-Cost Housing Policies for Kuala Lumpur Source: Hadi, 2014.

During the $10^{\text {th }}$ Malaysia Plan (2011-2015), the government implemented various housing programmes to provide sufficient and affordable housing for the poor as well as for the low and middle income households. The key question here is whether the government has adequate set of policies to combat the squatter's issues and problems in Malaysia. Based on all the policies and programs made by the government, there is no specific policy to eliminate squatters but strategies through the building of low-cost housing for low-income group. Therefore, the government and related agencies should take a serious action together to resolve this squatter problem from increasing.

\section{CONCLUSION}

Many efforts were carried out by the government since the beginning of the fiveyear Malaysia Plan. The early guidance was to reduce the number of poverty in Malaysia. Poverty had driven the rural communities to migrate and settled in the urban areas. The government had therefore introduced many policies and schemes to eradicate squatters hence started the low-cost housing programmes including the provision of public housing. Even though the Zero Squatter by 2005 mission was not fully achieved, it was extended to the year 2020. However, the delivery of low-cost housing could not meet the target. The federal and state governments have taken more systematic measure by imposing a quota percentage for low-cost housing for any housing scheme development. Nevertheless, Malaysia is still striving to eliminate squatters and provide a decent home for everyone. Malaysia has an abundant of housing policies and programmes, yet there are still squatters in the urban areas. This calls for further investigation especially into the effectiveness and the implementation of the policies. 


\section{ACKNOWLEDGEMENT}

The authors would like to thank the Ministry of Higher Education Malaysia for funding this research through the RACE grant (RACE/F2/SS8/UiTM/17) and Universiti Teknologi MARA (UiTM) for supporting the research.

\section{REFERENCES}

Abdul Aziz, F.A. (2012). The investigation of the implications of squatter relocations in high risk neighbourhoods in Malaysia (Doctorate dissertation). Newcastle University, Newcastle, United Kingdom.

Abdul Hadi, A. N. (2014). Housing policy and housing programme in Malaysia. Planning and Housing Development. Universiti Sains Malaysia.

Agus, M. R. (2005). Persetingganan di Malaysia: penduduk dan petempatan semula. Kuala Lumpur, Penerbitan Universiti Malaya.

Bakhtyar, B., Zaharim, A., Sopian, K., \& Moghimi, S. (2013). Housing for poor people: a review on low cost housing process in Malaysia. WSEAS Transactions on Environment and Development, 9(2), 126-136.

Besar J. A., Fauzi, R., \& Ghazali, A. S. (2012). Penilaian awal impak pelaksanaan dasar perumahan negara terhadap sektor perumahan di Kuala Lumpur. Geografia: Malaysian Journal of Society and Space, 8(6), 90-108.

Economic Planning Unit, (2013). Laporan kesejahteraan rakyat Malaysia. Retrieved January 12, 2016 from http://www.epu.gov.my/documents.

Economic Planning Unit. (2015). Rancangan Malaysia Kesepuluh 2011-2015. Putrajaya: Economic Planning Unit.

Economic Planning Unit (2016). Previous plans. Retrieved January 11, 2016 from http://www.epu.gov.my/en/development-plans/previous-plans.

Idrus, N., \& Ho, C. S. (2008, June). Affordable and quality housing through the low cost housing provision in Malaysia. Seminar of Sustainable Development and Governance. Toyohashi, Japan.

Jabatan Perancangan Bandar dan Desa (2013) Laporan kesejahteraan rakyat. Selangor: Jabatan Perancangan Bandar dan Desa.

Ministry of Urban Wellbeing Housing and Local Government (2015a). Program Pembangunan Setinggan. Available at http:ehome.kplt.gov.my/index.php/pages/view/42.(Retrieved: January 15, 2016).

Ministry of Urban Wellbeing Housing and Local Government (2015b). KPKT selected statistics 2015. Available at:http://ehome.kpkt.gov.my

Muhamad Ariff, N. R., \& Davies, H. (2009). Sustainable living environment for urban low-income households in Malaysia: key factors for maintenance. In Proceedings Of The 2009 International Symposium on Construction in Developing Economies: Commonalities among Diversities. Penang, Malaysia: CIBW. 
Yusfida Ayu Abdullah, Julieven Nonoi Kuek, Hazlina Hamdan, \& Farrah Lyana Mohd Zulkifli

Combating Squatters in Malaysia: Do We Have Adequate Policies as Instrument?

Murad, M. W., Hasan, M. M., Islam, M. S., \& Alam, M. M. (2014). Socio economic profile of the low income and poor communities in Kuala Lumpur city, Malaysia. International Journal of Ethics in Social Sciences, 2(1), 113-130.

National Housing Council (2016). Program Perumahan Rakyat (PPR). Available at: http://ehome.kpkt.gov.my/ehome/profil/pprdisewa.ctm

National Housing Department (2007). Towards successful housing development in Malaysia. Retrieved January 3, 2010, from http://ehome.kpkt.gov.my/ehome/ehomebi/profil/artikel4.cfm.

Shresta, R., Tuladhar, A., Zevenbergen, J., \& Banskota, M. (2014, June). Decades of struggle of space: about the legitimacy of informal settlements in urban areas. XXV International Federation of Surveyors Congress. Kuala Lumpur, Malaysia.

Shuid, S. (2004, February). Low medium cost housing in Malaysia: issue and challenges. Asia Pacific Network for Housing Research Conference $(A P N H R)$. Hong Kong.

Sufian, A. (2009). Equitable Distribution of Low-Cost Houses: A Malaysian Legal Perspective. COBRA 2009 RICS Research Conference. Cape Town, South Africa.

Tan, T. H. (2011). Sustainability and housing provision in Malaysia. Journal of Strategic Innovation \& Sustainability, 7(1), 62-71.

Ubale, M. Y., Martin, D. J., \& Seow, T. (2012, December). The current practices of the Malaysian formal low cost housing provision system. International Conference of Technology Management, Business and Entrepreneurship 2012 (ICTMBE2012). Melaka, Malaysia.

$\mathrm{UN}-\mathrm{Habitat}$ (2008). The role of government in the housing market: the experiences from Asia. Nairobi: UN-Habitat. 